\title{
HUBUNGAN FAKTOR PEKERJAAN DENGAN KELELAHAN KERJA PADA PEKERJA LAPANGAN PROYEK PEMBANGUNAN GEDUNG PT. X DI JAKARTA PUSAT TAHUN 2020
}

\author{
Kartini Muladame Sejati Sihotang ${ }^{1 *}$, Rizki Amalia ${ }^{1}$, Fathinah Ranggauni Hardy ${ }^{1}$, Fandita \\ Tonyka Maharani ${ }^{1}$ \\ ${ }^{1}$ Peminatan Keselamatan dan Kesehatan Kerja - Kesehatan Lingkungan, \\ Fakultas IImu Kesehatan, Universitas Pembangunan Nasional Veteran Jakarta \\ ${ }^{2}$ Program Studi Kesehatan Masyarakat Program Sarjana, Fakultas IImu Kesehatan, Universitas \\ Pembangunan Nasional Veteran Jakarta \\ *Corresponding author: kartinimuladame07@gmail.com
}

\begin{abstract}
Work fatigue can be determined by weakening the worker's body, impacting physical and mental performance decreasing. Job-related factors are one of the factors causing work fatigue, such as work duration, physical workload, and mental workload. This study aimed to determine the association between job factors and work fatigue among workers in PT. $X$ building construction site at Central Jakarta. The variables research included work fatigue, work duration, physical workload, and mental workload. The research method used was quantitative analytic with a cross-sectional design. The research instrument used the IFRC questionnaire, NASA-TLX questionnaire, and pulse oxymeter. This research sample was 109 workers obtained with the accidental sampling technique, and data analyzed using the chi-square test. The results show that 50 workers (45.9\%) had experienced a moderate category of work fatigue. The statistical analysis results showed a significant relationship between work duration ( $p$-value $=0.000$ ) and physical workload $(p$-value $=0.000)$ with work fatigue. Suggestions that need to be implemented by the company are to regulate work time and overtime according to applicable regulations and divide work shifts.
\end{abstract}

Keywords : Determinant of Work, Work Fatigue, Construction Workers

\section{PENDAHULUAN}

Kunci dalam menggerakkan pembangunan bangsa Indonesia di era globasasi terletak pada kegiatan pengembangan dunia industri. Hal ini dapat dicapai melalui berbagai kegiatan di sektor konstruksi 1. Sektor konstruksi merupakan sektor pekerjaan di bidang industri yang berpotensi besar terhadap terjadinya kecelakaan kerja karena berkaitan erat dengan karakteristik proyek yang spesifik, terbukanya lingkungan kerja, banyak titik lokasi kerja, terbatasnya target waktu pelaksanaan, sampai dituntutnya ketahanan fisik yang tinggi saat bekerja 2,3. Kecelakaan kerja di sektor konstruksi dipicu banyak faktor, salah satunya ialah kelelahan ${ }^{4}$.

Berdasarkan data International Labour Organization (ILO) menunjukkan sekitar 32\% pekerja di dunia mengalami kelelahan akibat aktivitas pekerjaan dengan prevalensi kelelahan di industri sebesar $45 \%{ }^{5}$. Penelitian National Safety Council terhadap 2.010 pekerja industri di Amerika Serikat tahun 2017 menyebutkan bahwa sebanyak $45 \%$ pekerja konstruksi mengalami kecelakaan kerja yang disebabkan oleh kelelahan dengan menyumbang angka persentase sebesar $94 \%$ 6 . Data yang diterbitkan oleh BPJS Ketenagakerjaan mencatat pekerja konstruksi menempati posisi teratas untuk yang paling sering alami kecelakaan kerja dengan jumlah kasus yang meningkat setiap tahunnya. Ditinjau dari data tahun 2016 terdapat 101.368 kasus menjadi 124.041 kasus pada tahun 2017 sampai tahun 2019 mencapai angka 130.923 kasus kecelakaan kerja di sektor konstruksi dengan faktor penyebab utama yaitu kelelahan?.

Kelelahan merupakan kondisi yang paling sering dialami oleh setiap orang dengan ditandai oleh menurunnya kekuatan untuk menjalani suatu kegiatan ${ }^{8}$. Keadaan lelah secara fisik atau mental sebagai akibat dari aktivitas pekerjaan yang terjadi dalam waktu yang lama dan kemudian akan dapat mengurangi kemampuan seseorang untuk bekerja dengan aman dan efektif diartikan sebagai kelelahan kerja ${ }^{9}$. Kelelahan kerja dapat diartikan juga sebagai kondisi melemahnya fisik tubuh, kegiatan, dan motivasi saat menyelesaikan pekerjaan ${ }^{10}$. Selain itu, tugas pekerjaan yang membosankan karena 


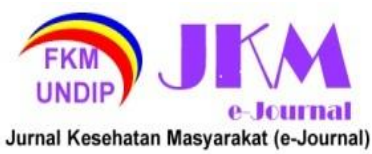

sifatnya yang berulang dan waktu kerja yang panjang akan dapat meningkatkan kondisi lelah pada pekerja ${ }^{11,12}$.

Undang - Undang Nomor 11 tahun 2020 tentang Cipta Kerja telah menetapkan waktu kerja yang wajib dipatuhi oleh pemilik tempat kerja, tepatnya pada pasal 77 menyebutkan batasan waktu kerja yang meliputi 7 jam/hari dan $40 \mathrm{jam} / \mathrm{minggu}$ selama enam hari kerja serta $8 \mathrm{jam} / \mathrm{hari}$ dan $40 \mathrm{jam} / \mathrm{minggu}$ selama lima hari kerja. Maurits (2012) mengungkapkan bahwa waktu kerja yang panjang menyebabkan sedikitnya penerimaan jam istirahat sehingga dapat menimbulkan kelelahan ${ }^{13}$.

Pemberian beban kerja sebesar 30 sampai $40 \%$ dari kapasitas yang dimiliki pekerja dapat menyebabkan terjadinya kelelahan kerja. Notoatmodjo (2014) mengungkapkan mengenai maksud dari beban bagi pekerja yang merupakan seluruh jenis pekerjaan yang membutuhkan kekuatan otot fisik atau pemikiran. Beban kerja tersebut diantaranya beban fisik, mental, atau sosial ${ }^{14}$. Setiap pekerja harus menerima beban kerja yang sesuai dengan kemampuannya baik secara fisik, kognitif, sampai keterbatasan yang dimilikinya. Tidak seimbangnya antara porsi tuntutan pekerjaan dengan kemampuan pekerja akan mengakibatkan beberapa masalah seperti rasa tidak nyaman, lelah, cedera hingga kecelakaan ${ }^{15}$.

PT. X merupakan sebuah perusahaan konstruksi di Indonesia yang mengerjakan berbagai proyek pembangunan seperti sarana transportasi, institusi pendidikan, gedung, dan sebagainya. Salah satu proyek yang sedang dijalani oleh PT. $X$ dalam periode menuju akhir tahun 2020 adalah pembangunan gedung yang berlokasi di Jakarta Pusat. Kegiatan proyek ini telah berjalan sejak Agustus 2020 dan diperkirakan selesai dalam kurun waktu selama 2 tahun mendatang. Proyek ini direncanakan akan membangun dua gedung dengan masing-masing berjumlah 5 lantai dan 1 lantai basement.

Berdasarkan kondisi nyata di Proyek Pembangunan Gedung PT. X, mayoritas pekerja bekerja selama 12 jam dalam sehari karena lembur hingga malam bahkan bisa sampai pagi hari saat ada kegiatan pengecoran. Seluruh pekerja menjalani tujuh hari kerja dalam satu minggu. Jam kerja normal para pekerja berlangsung selama tujuh jam dalam satu hari yang dimulai dari pukul 08.00 sampai 16.00 WIB dengan satu jam waktu istirahat pada pukul 12.00 sampai 13.00 WIB. Jika lembur, terdapat penambahan satu jam waktu isirahat yang berkisar dari pukul 18.00 sampai 19.00 WIB lalu kembali bekerja hingga pukul 22.00 WIB. Pengaturan waktu kerja yang diberlakukan tidak sesuai dengan durasi yang ditetapkan dalam Undang-Undang Nomor 11 Tahun 2020 tentang Cipta Kerja. Tepatnya pada pasal 77 ayat 2 (a) menyatakan ketentuan waktu kerja yaitu 7 jam/hari atau 40 jam/minggu bagi yang bekerja selama 6 hari kerja dalam satu minggu. Dalam peraturan, tidak disebutkan aturan waktu kerja yang dilaksanakan selama satu minggu penuh. Maka dari itu, ketentuan waktu kerja di proyek tersebut sudah melampaui peraturan yang berlaku baik dari segi jam dan hari kerja. Disamping itu, terdapat pemenuhan target pekerjaan dalam kurun waktu tertentu yang harus dikerjakan oleh pekerja sehingga mendapatkan jatah lembur tiap minggunya. Kekuatan tenaga fisik yang besar sangat diperlukan untuk mencapai target pekerjaan dengan tepat waktu. Tuntutan pekerjaan yang dibebankan kepada pekerja tidak hanya memengaruhi secara fisik saja namun aspek mental juga ikut andil memberikan pengaruh yang besar pula. Hal ini dapat menimbulkan beban kerja fisik dan mental pada pekerja yang kemudian akan berujung terhadap munculnya kelelahan kerja.

Berdasarkan uraian diatas, maka penting dilakukan penelitian guna mengetahui hubungan antara faktor pekerjaan dengan kelelahan kerja pada pekerja lapangan proyek pembangunan gedung PT. $X$ di Jakarta Pusat tahun 2020.

\section{METODE PENELITIAN}

Penelitian bersifat analitik kuantitatif dengan pendekatan cross-sectional yang bertujuan untuk mengetahui hubungan faktor pekerjaan dengan kelelahan kerja pada pekerja lapangan proyek pembangunan gedung PT. X. Populasi penelitian ini yaitu seluruh pekerja lapangan proyek yang berjumlah 150 orang. Variabel dalam penelitian ini Variabel independen penelitian meliputi durasi kerja, beban kerja fisik, dan beban kerja mental sedangkan untuk variabel dependen penelitian ini adalah kelelahan kerja. Pengambilan data kelelahan kerja sebagai variabel dependen menggunakan kuesioner Industrial Fatigue Research Comittee (IFRC) sedangkan data variabel independen yaitu durasi kerja didapatkan dari kuesioner informasi durasi kerja, beban kerja mental dinilai melalui kuesioner NASA Task Load Index (NASA-TLX), dan beban kerja fisik diukur menggunakan alat ukur yang dinamakan pulse oxymeter. Teknik pengambilan sampel yang digunakan adalah 


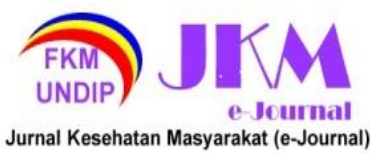

accidental sampling dengan jumlah sampel sebanyak 109 pekerja. Analisis data yang digunakan yaitu univariat dan bivariat dengan menggunakan uji statistik melalui chi-square. Derajat kepercayaan yang digunakan sebesar $95 \%$. Penelitian dilaksanakan dari November 2020 sampai Januari 2021.

HASIL

Analisis Univariat

Analisis univariat pada penelitian ini terdiri dari karakteristik pekerja serta variabel yang diteliti mencakup dependen dan independen. Berdasarkan tabel 1, diketahui bahwa sebagian besar pekerja berusia $\geq 30$ tahun, berpendidikan rendah di jenjang SD sampai SMP, berstatus sudah menikah, dan bekerja di bagian bekisting. Tabel 2 diperoleh hasil bahwa mayoritas pekerja mengalami kelelahan kerja kategori sedang, memiliki durasi kerja $>7$ jam dalam satu hari, memiliki beban kerja mental dengan kategori sedang, dan memiliki beban kerja fisik yang berat sehingga perlu redesign pekerjaan seperti metode kerja yang kurang ergonomis akan memberi beban kerja yang berlebih sehingga perlu perbaikan metode kerja dan penyediaan alat bantu kerja.

Tabel 1. Distribusi Frekuensi Karakteristik pada Pekerja Lapangan Proyek Pembangunan Gedung PT. X di Jakarta Pusat Tahun 2020

\begin{tabular}{|c|c|c|}
\hline Karakteristik & \multicolumn{2}{|c|}{$\begin{array}{cc}\begin{array}{c}\text { Frekuensi } \\
\text { (n) }\end{array} & \begin{array}{c}\text { Persentase } \\
(\%)\end{array}\end{array}$} \\
\hline Usia & & \\
\hline$<30$ tahun & 48 & 44 \\
\hline $\begin{array}{l}\geq 30 \text { tahun } \\
\text { Pendidikan }\end{array}$ & 61 & 56 \\
\hline $\begin{array}{l}\text { Rendah } \\
\text { (SD SMP) }\end{array}$ & 71 & 65,1 \\
\hline Tinggi (SMA) & 38 & 34,9 \\
\hline Status & & \\
\hline $\begin{array}{l}\text { Pernikahan } \\
\text { Belum Menikah }\end{array}$ & & \\
\hline Sudah & & \\
\hline Menikah & 14 & 1,9 \\
\hline $\begin{array}{l}\text { Bagian } \\
\text { Pekerjaan }\end{array}$ & & \\
\hline Bekisting & 33 & 30,3 \\
\hline Dewatering & 6 & 5,5 \\
\hline $\begin{array}{l}\text { Mechanical } \\
\text { Electric }\end{array}$ & 9 & 8,3 \\
\hline Pembesian & 21 & 19,3 \\
\hline Pengecoran & 15 & 13,8 \\
\hline Pengelasan & 9 & 8,3 \\
\hline Penggalian & 16 & 14,7 \\
\hline Total & 109 & 100 \\
\hline
\end{tabular}

Tabel 2. Distribusi Frekuensi Variabel pada Pekerja Lapangan Proyek Pembangunan Gedung PT. X di Jakarta Pusat Tahun 2020

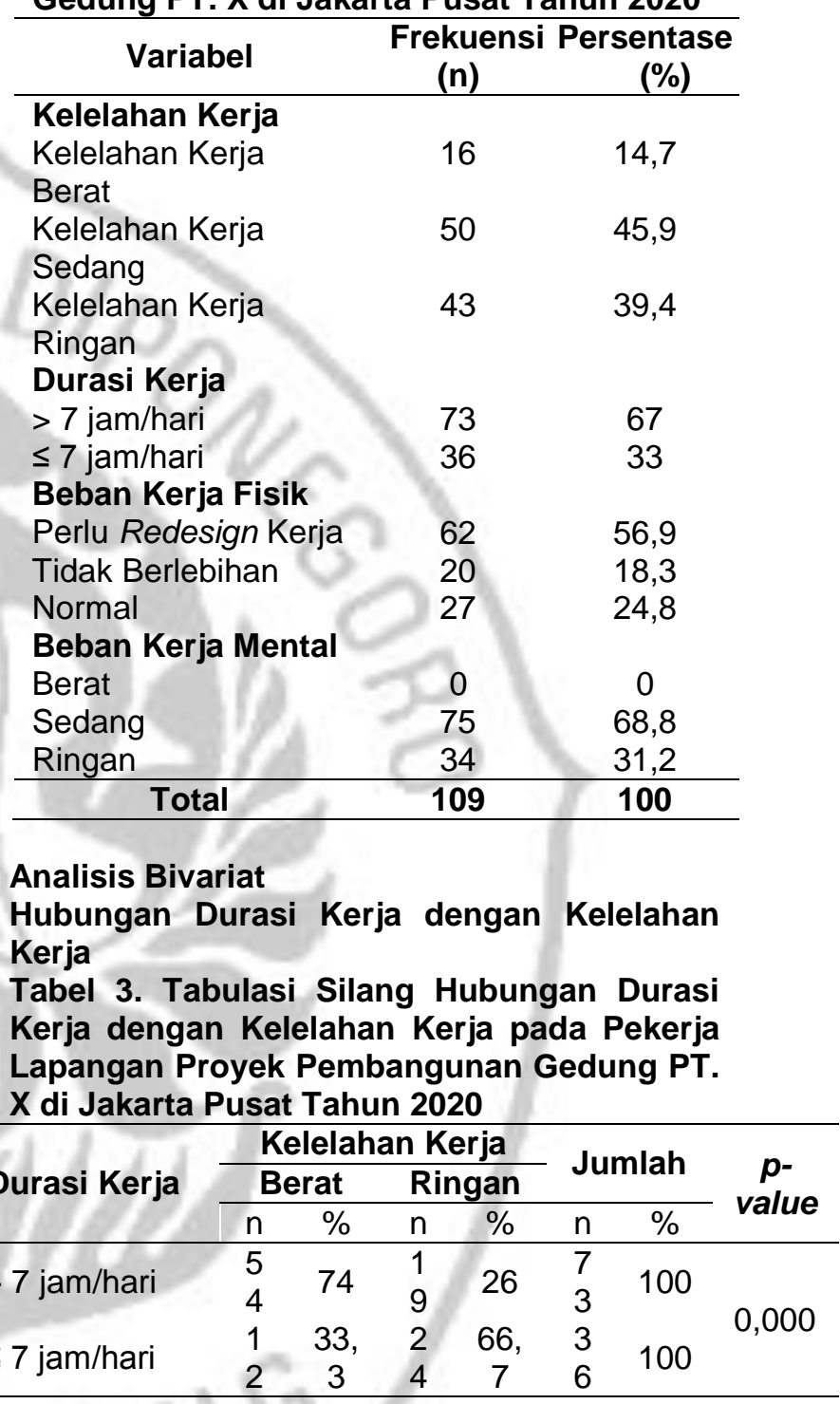

Berdasarkan tabel 3, dapat dilihat bahwa kelelahan kerja berat paling banyak dialami oleh pekerja yang bekerja selama lebih dari 7 jam dalam sehari yaitu sebanyak 54 orang (74\%) dibandingkan dengan pekerja yang bekerja $\leq 7$ jam dalam sehari yaitu sebanyak 12 orang $(33,3 \%)$. Hasil uji statistik diperoleh $p$ value sebesar 0,000 sehingga dapat disimpulkan bahwa adanya hubungan yang signifikan antara durasi kerja dengan kelelahan kerja. 


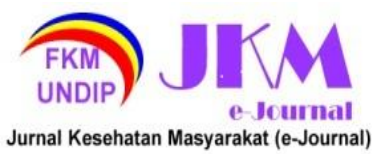

Jurnal Kesehatan Masyarakat (e-Journal)
JURNAL KESEHATAN MASYARAKAT (e-Journal)

Volume 9, Nomor 5, September 2021

ISSN: 2715-5617 / e-ISSN: 2356-3346

http://ejournal3.undip.ac.id/index.php/jkm Hubungan Beban Kerja Fisik dengan
Kelelahan Kerja

Tabel 4 Tabulasi Silang Hubungan Beban Kerja Fisik dengan Kelelahan Kerja pada Pekerja Lapangan Proyek Pembangunan Gedung PT. X di Jakarta Pusat Tahun 2020

\begin{tabular}{|c|c|c|c|c|c|c|}
\hline \multirow{3}{*}{$\begin{array}{c}\text { Beban } \\
\text { Kerja } \\
\text { Fisik }\end{array}$} & \multicolumn{4}{|c|}{ Kelelahan Kerja } & \multirow{3}{*}{$\begin{array}{c}\begin{array}{c}\text { Jumla } \\
\mathbf{h}\end{array} \\
\mathrm{n} \\
\end{array}$} & \multirow{2}{*}{-value } \\
\hline & \multicolumn{2}{|c|}{ Berat } & \multicolumn{2}{|c|}{ Ringan } & & \\
\hline & $\mathrm{n}$ & $\%$ & $n$ & $\%$ & & \\
\hline Berat & 49 & 79 & 13 & 2 & & \\
\hline Ringan & 17 & $\begin{array}{c}36, \\
2\end{array}$ & 49 & & & 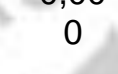 \\
\hline
\end{tabular}

Berdasarkan tabel 4, diperoleh bahwa pekerja yang memiliki beban kerja fisik berat yang paling banyak mengalami kelelahan kerja berat yaitu sebanyak 49 orang (79\%) dibandingkan dengan pekerja yang memiliki beban fisik ringan yaitu sebanyak 17 orang $(36,2 \%)$. Hasil uji statistik menunjukkan $p$-value sebesar 0,000 sehingga dapat disimpulkan bahwa terdapat hubungan yang signifikan antara beban kerja fisik dengan kelelahan kerja. Hubungan Beban Kerja Mental dengan Kelelahan Kerja

Tabel 5 Tabulasi Silang Hubungan Beban Kerja Mental dengan Kelelahan Kerja pada Pekerja Lapangan Proyek Pembangunan Gedung PT. X di Jakarta Pusat Tahun 2020

\begin{tabular}{cccccccc} 
Beban & \multicolumn{4}{c}{ Kelelahan Kerja } & \multicolumn{2}{c}{ Jumlah } & \multirow{2}{*}{$\boldsymbol{p}$ - } \\
\cline { 2 - 6 } $\begin{array}{c}\text { Kerja } \\
\text { Mental }\end{array}$ & \multicolumn{2}{c}{ Berat } & \multicolumn{2}{c}{ Ringan } & & & value \\
\hline Sedang & 48 & 64 & 27 & 36 & 75 & 100 & \\
Ringan & 18 & 52, & 16 & 47, & 34 & 100 & 0,377 \\
& 9 & 16 & 1 & & & \\
\hline
\end{tabular}

Berdasarkan tabel 5, diketahui bahwa pekerja yang mengalami kelelahan kerja berat paling banyak dialami oleh pekerja yang memiliki beban kerja mental sedang yaitu sebanyak 48 orang (64\%) dibandingkan pekerja yang memiliki beban kerja mental ringan yaitu sebanyak 18 orang $(52,9 \%)$. Hasil uji statistik menunjukkan $p$-value sebesar 0,377 $(p>0,05)$ dengan kesimpulan yaitu tidak berhubungan signifikan antara beban kerja mental dengan kelelahan kerja.

\section{PEMBAHASAN}

Hubungan Durasi Kerja dengan Kelelahan Kerja
Penelitian ini sejalan dengan penelitian yang dilakukan oleh Hastuti pada tahun 2015 dengan hasil $p$-value sebesar 0,002 yang menunjukkan adanya hubungan antara durasi kerja dengan kelelahan kerja ${ }^{16}$. Penelitian yang dilakukan oleh Syahputra dan Lestari tahun 2019 juga ikut menyatakan bahwa terdapat hubungan antara lamanya durasi bekerja dengan kelelahan kerja yang memiliki $p$-value sebesar 0,002 17 .

Mayoritas pekerja proyek pembangunan gedung PT. $X$ yang mengalami kelelahan kerja tingkat berat dikarenakan bekerja lebih dari 7 jam dalam sehari. Hal ini dipengaruhi oleh tuntutan pekerjaan dari perusahaan terkait sehingga diharuskan untuk lembur sampai malam bahkan keesokan pagi harinya. Aktivitas pekerjaan dilakukan setiap hari mulai Senin hingga Minggu dari pukul $08.00 \mathrm{WIB}$. Hal ini bertentangan dengan peraturan yang berlaku di Indonesia, tercantum dalam Undang- Undang Nomor 11 Tahun 2020 tentang Cipta Kerja.

Umumnya pekerja dapat bekerja dengan baik selama 6 sampai 10 jam dalam sehari atau 40 sampai 50 jam dalam seminggu. Bekerja melampaui waktu kerja yang optimal dapat menimbulkan berbagai masalah seperti kelelahan, gangguan kesehatan, penyakit, kecelakaan, ketidakpuasaan hingga penurunan kualitas dan hasil kerja ${ }^{18}$. Liu et al (2018) ikut mengemukakan bahwa lamanya waktu kerja dapat berdampak pada peningkatan beban kardiovaskular ${ }^{17}$.

Hubungan Beban Kerja Fisik dengan
Kelelahan Kerja
Penelitian ini selaras dengan penelitian yang dijalani oleh Arifin tahun 2017 yang menyatakan bahwa ada hubungan antara beban kerja fisik dengan kelelahan kerja, dimana diperoleh nilai $p$ sebesar 0,036 ${ }^{19}$. Penelitian yang dilakukan oleh Wulandari dkk pada tahun 2016 juga menyatakan hubungan antara beban kerja fisik dan kelelahan kerja dengan $p$-value sebesar $0,001(<0,05){ }^{1}$.

Aktivitas pekerjaan di proyek pembangunan gedung ini lebih dominan menggunakan tenaga fisik dari pekerja dibandingkan penggunaan alat berat konstruksi. Para pekerja menggunakan kekuatan dari tenaga fisiknya dalam bekerja seperti merangkai penyangga beton, memindahkan material bahan bangunan, menggali lahan terutama pada bagian yang sulit dijangkau oleh alat berat. Selain itu, pekerja lebih sering bekerja dalam posisi berdiri dengan waktu yang lama. Alasan inilah yang menyebabkan para pekerja proyek 


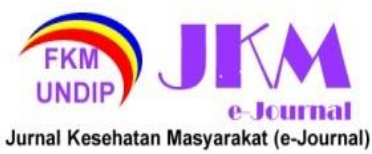

pembangunan PT. $X$ banyak yang mengalami kelelahan kerja berat karena intensitas penggunaan tenaga fisik pekerja lebih besar dibandingkan pemakaian alat bantu kerja.

Proses kerja yang melibatkan aktvitas fisik akan menyebabkan peningkatan denyut nadi kerja seiring dengan semakin tingginya beban kerja fisik yang dikerjakan oleh seorang pekerja. Nadi kerja berperan untuk menyelesaikan suatu pekerjaan dengan baik. Oleh karena itu, jika terjadi peningkatan denyut nadi maka tingkat kelelahan yang dialami oleh pekerja juga akan semakin tinggi sehingga dapat berdampak pada penurunan hasil kerja 20. Disamping itu, Maharaja (2009) menjelaskan bahwa tingginya beban kerja fisik akan sejalan dengan kebutuhan oksigen yang semakin meningkat. Tubuh memerlukan oksigen yang cukup untuk melakukan proses aerobik. Jika tidak mencukupi kadar oksigen dalam tubuh maka akan terjadi peningkatan asam laktat sehingga dapat menimbulkan kelelahan pada orang tersebut ${ }^{21}$.

\section{Hubungan Beban Kerja Mental dengan Kelelahan Kerja \\ Penelitian ini tidak sama seperti} penelitian yang dilakukan oleh Rahamwati dan Tualeka di tahun 2019 yang menyatakan bahwa beban kerja mental memiliki hubungan dengan kelelahan kerja ${ }^{22}$. Namun sejalan dengan penelitian yang dilakukan Ningsih dkk pada tahun 2018 dengan hasil penelitian yang menunjukkan tidak adanya hubungan antara beban kerja dengan kelelahan dimana $p$-value sebesar 0,088 $(>0,05)^{23}$.

Penyebab dari tidak adanya hubungan yang bermakna dalam penelitian ini dapat disebabkan oleh pendistribusian data yang tidak merata yang dimana frekuensi pekerja yang mengalami kelelahan kerja berat paling banyak dialami oleh pekerja yang memiliki beban kerja mental sedang dibandingkan pekerja yang berbeban mental ringan. Berdasarkan keseluruhan hasil wawancara terhadap responden, diketahui tidak adanya responden yang memiliki beban kerja mental tinggi. Hal ini terjadi karena sebagian besar pekerja mengakui bahwa mereka lebih terbebani secara fisik dibandingkan mental akibat pemberian tuntutan pekerjaan. Namun tidak menutup kemungkinan mereka juga terbeban secara mental karena ditekan untuk bekerja cepat dan tepat sesuai dengan alur progress yang disusun oleh pihak perusahaan.

\section{KESIMPULAN}

Hasil penelitian yang dilakukan pada proyek pembangunan gedung PT. $X$ di Jakarta Pusat tahun 2020, dapat disimpulkan berdasarkan analisis univariat dari karakteristik pekerja, diperoleh hasil bahwa sebagian besar pekerja berusia lebih dari atau sama dengan 30 tahun (56\%), berpendidikan rendah di jenjang SD sampai SMP $(65,1 \%)$, berstatus sudah menikah $(67,9 \%)$, dan berasal dari bagian pekerjaan bekisting (30,3\%). Berdasarkan analisis univariat dari variabel dependen dan independen penelitian, diketahui bahwa sebagian besar pekerja mengalami kelelahan kerja kategori sedang $(45,9 \%)$, bekerja selama lebih dari 7 jam dalam sehari (67\%), memiliki beban kerja fisik yang berat sehingga diperlukan untuk meredesign pekerjaannya $(56,9 \%)$, dan memiliki beban kerja mental kategori sedang $(68,8 \%)$. Terdapat hubungan yang signifikan antara durasi kerja ( $p$-value $=$ $0,000)$ dan beban kerja ( $p$-value $=0,000)$ dengan kelelahan kerja sedangkan untuk variabel beban kerja mental tidak memiliki hubungan yang signifikan terhadap kelelahan kerja $(p$-value $=0,377)$.

\section{SARAN}

Bagi Perusahaan perlu mengatur kembali waktu kerja dan membuat kebijakan waktu lembur sesuai dengan peraturan yang termuat di Undang-Undang Nomor 11 Tahun 2020 yaitu bekerja selama 7 jam/hari untuk 6 hari kerja selama satu minggu sedangkan waktu lembur kerja hanya diberikan maksimal 4 jam/hari dan 18 jam dalam seminggu, mengatur pembagian shift kerja dan melakukan penambahan pekerja untuk mengurangi risiko kejadian kecelakaan kerja akibat kelelahan, dan menyediakan alat bantu kerja guna meringankan beban kerja fisik pada pekerja seperti troli dan forklift. Bagi Pekerja perlu memanfaatkan waktu istirahat dengan sebaik mungkin dan melakukan peregangan otot untuk mengurangi kelelahan kerja. Bagi Peneliti Selanjutnya perlu mengganti instrumen kelelahan yang obyektif dan menambahkan variabel pada faktor pekerjaan maupun faktor lainnya. 


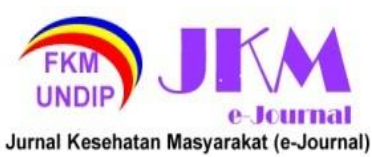

\section{DAFTAR PUSTAKA}

1. Wulandari K, Widjasena B, Ekawati E. Hubungan Beban Kerja Fisik Manual Dan Iklim Kerja Terhadap Kelelahan Pekerja Konstruksi Bagian Project Renovasi Workshop Mekanik. J Kesehat Masy. 2016;4(3):425-35.

2. Ramdan IM, Handoko HN. Kecelakaan Kerja Pada Pekerja Konstruksi Informal Di Kelurahan "X " Kota Samarinda Work Accident of Informal Construction Workers in District " $X$ " Samarinda City. J Mkmi. 2016;12(1):1-6.

3. Alfiansah Y, Kurniawan B, Ekawati. Analisis Upaya Manajemen K3 Dalam Pencegahan Dan Pengendalian Kecelakaan Kerja Pada Proyek Konstruksi PT. X Semarang. J Kesehat Masy. 2020;8(September):1-6.

4. Ningsih SNP, Nilamsari N. Faktor Yang Berhubungan Dengan Kelelahan Pada Pekerja Dipo Lokomotif Pt . Kereta Api Indonesia ( Persero ). J Ind Hyg Occup Heal. 2018;3(1):69-82.

5. ILO. Workplace Stress: a collective challenge [Internet]. International Labour Organizatio (ILO). 2016. 57 p. Available from: https://www.ilo.org/global/topics/safetyand-health-at-work/resources-

library/publications/WCMS_466547/lan g--

en/index.htm\%0Ahttp://www.ilo.org/afri $\mathrm{ca} /$ media-

centre/news/WCMS_477712/lang--

en/index.htm

6. National Safety Counsil. Fatigue in The Workplace: Causes \& Consequences of Employee Fatigue. In 2017.

7. Friyandary $\mathrm{B}$, Insan $\mathrm{T}$, Lestari RA. Kajian Literatur Analisis Risiko Keselamatan Kerja dengan Metode Kualitatif pada Proyek Konstruksi di Indonesia: Sebuah Review. 2020;33144.

8. Budiono AMS, Jusuf RMS, Pusparini A. Bunga Rampai Hiperkes \& KK. Semarang: Badan Penerbit Universitas Diponegoro; 2016.

9. Mustofani. Hubungan Faktor Internal Dengan Kelelahan Subjektif Pekerja. Med Technol Public Heal J. 2020;4(1):61-9.

10. Maharja R. Analisis Tingkat Kelelahan Kerja Berdasarkan Beban Kerja Fisik Perawat Di Instalasi Rawat Inap RSU Haji Surabaya. Indones J Occup Saf Heal. 2015;4(1):93
11. Canadian Centre for Occupational Health \& Safety. Fatigue: OSH Answers [Internet]. 2017 [cited 2020 Oct 17]. Available from: https://www.ccohs.ca//oshanswers/psy chosocial/fatigue.html

12. Eurofound and International Labour Organization. Working conditions in a global perspective [Internet]. 2019. 196 p. Available from: https://www.eurofound.europa.eu/publi cations/report/2019/working-

conditions-in-a-global-perspective

13. Datu MMD, Kawatu PAT, Mandagi CKF. Hubungan Antara Lama Kerja dengan Kelelahan Kerja pada Pengendara Ojek Online Komunitas Manguni Rider Online Sario. J KESMAS. 2019;8(6):601-7.

14. Anisyah TD, Saptadi JD. Hubungan Antara Waktu Kerja Dan Beban Kerja Fisik Dengan Perasaan Kelelahan Pada Pekerja Di Home Industry Tahu Di Dukuh Janten. Kampurui J Kesehat Masy. 2020;2(1):36-41.

15. Oesman TI, Simanjuntak RA. Hubungan Faktor Internal Dan Eksternal Terhadap Kelelahan Kerja Melalui Subjective Self Rating Test. Natl Conf Indones Ergon Soc. 2011;268-76.

16. Hastuti DD. Hubungan Antara Lama Kerja Dengan Kelelahan Pada Pekerja Kontruksi Di PT. Nusa Raya Cipta Semarang. Skripsi. 2015;154.

17. Syaputra B, Lestari PW. Pengaruh Waktu Kerja Terhadap Kelelahan pada

Pekerja Konstruksi Proyek X di Jakarta Timur. 2019;1:103-7.

18. Suma'mur. Higiene Perusahaan dan Kesehatan Kerja (HIPERKES). Jakarta: Sagung Seto; 2014.

19. Arifin MAS. Faktor Yang Berhubungan Dengan Kelelahan Kerja Pada Pekerja Konstruksi Proyek Nipah Mall Kota Makassar Tahun 2017. Skripsi. 2017;

20. Kusgiyanto W, Suroto, Ekawati. Analisis Hubungan Beban Kerja Fisik, Masa Kerja, Usia, Dan Jenis Kelamin Terhadap Tingkat Kelelahan Kerja Pada Pekerja Bagian Pembuatan Kulit Lumpia Di Kelurahan Kranggan Kecamatan Semarang Tengah. J Kesehat Masy. 2017;5(5):413-23.

21. Zahrotunnisa W, Ekawati E, Jayanti S. Hubungan Asupan Energi, Kualitas Tidur, Beban Kerja Fisik Dan Postur Kerja Dengan Kelelahan Kerja Pada 
Guru Taman Kanak Kanak. Kesmas Indones. 2020;12(1):33.

22. Rahmawati ND, Tualeka AR. Correlation between Individual Characteristics, Workload, and Noise with Work Fatigue. Indones J Occup Saf Heal. 2019;8(2):139-49.

23. Ningsih E, Muis M, Rahim MR.
Hubungan Stres Kerja Dan Beban Kerja Mental Dengan Kelelahan Kerja Perawat Rawat Inap Rs Unhas. 2018;1-13.

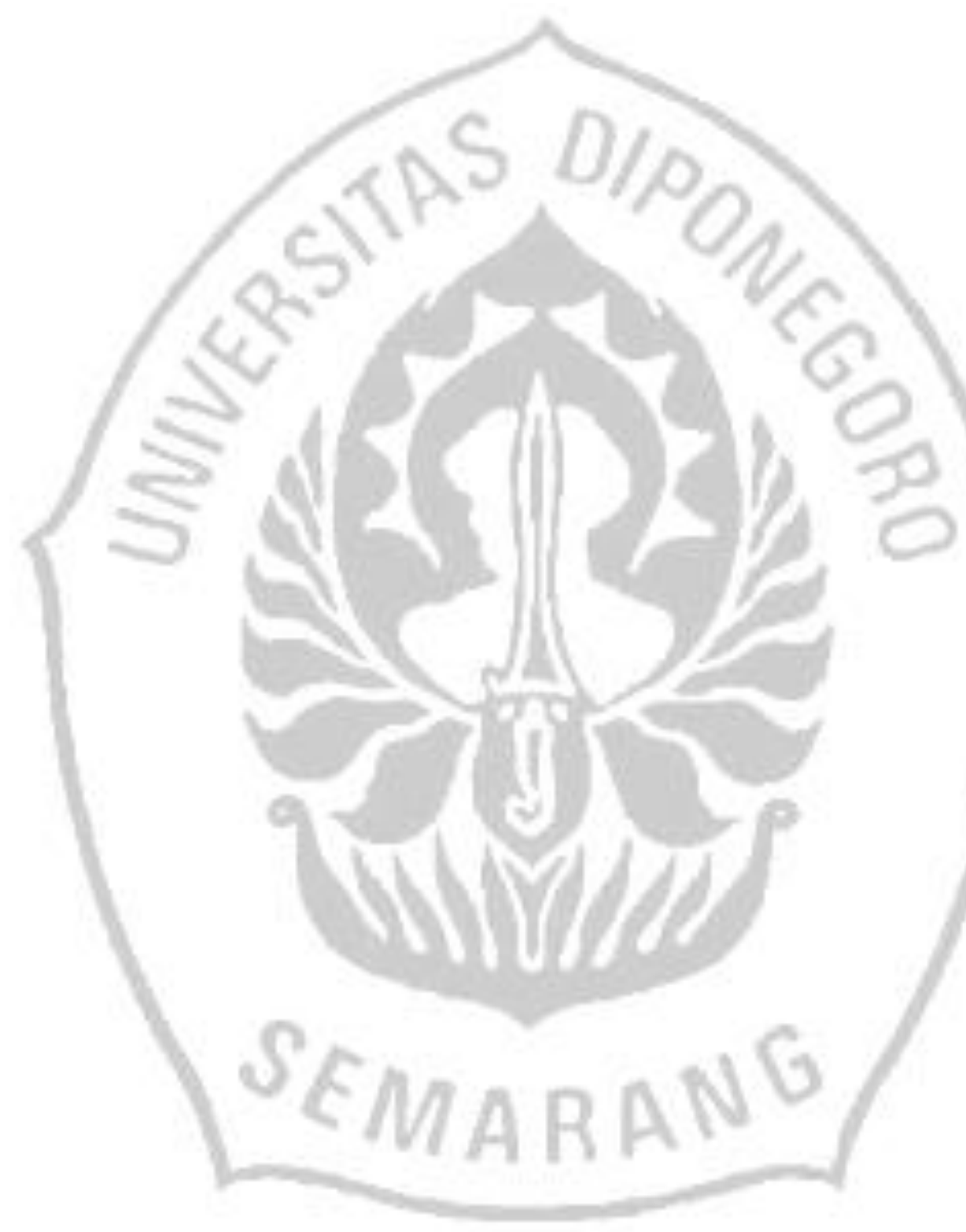

